\title{
Nigeria: Volunteer Vigilantism and Counter-Insurgency in the North-East
}

\author{
Okoli Al CHUKWUMA
}

\begin{abstract}
The ambience of unconventional violence orchestrated by Boko Haram insurgents in North-East Nigeria has occasioned precarious civil and humanitarian atmosphere in that area. The exigency of the situation has necessitated an equally unconventional civil security response, as exemplified in the involvement of volunteer vigilantes in counter-insurgency operations of the state. Relying on a synthesis of primary and secondary research, based respectively on field interviews/ discussions and library/desk sources, the paper evaluates the role of volunteer vigilantes in the fight against Boko Haram insurgents in North-East Nigeria. The paper posits that the outcome of this emergency approach to security has been largely inconsistent and seemingly contradictory: while the vigilantes have been effective in degrading the strongholds of the insurgents through localized reconnaissance and counter-offensives in collaboration with the military, they have also contributed to intensifying the insurgency by engendering selective reprisals attacks by the insurgents on communities that are associated with the vigilante forces. Coupled with their manifest negative attitude to human rights, as well as their seeming potential for disintegration into amorphous armed militias in the aftermath of the counter-insurgency operations, the paper submits that the involvement of volunteer vigilantes in counter-insurgency is a dicey strategic option given the fragile security regime in Nigeria wherein the practice is liable to counter-productive and abusive outcomes.
\end{abstract}

Keywords: Boko Haram, counter-insurgency, North East Nigeria, volunteer, vigilante, vigilantism.

\section{Introduction}

The atmosphere of unconventional violence orchestrated by Boko Haram insurgents in North-East Nigeria has occasioned precarious civil and humanitarian atmosphere in that area. The exigency of the situation has necessitated an equally unconventional civil security response, as exemplified in

\section{Okoli Al CHUKWUMA}

Ph.D, Department of Political Science

Federal University Lafia,

Nasarawa State, Nigeria

E-mail: okochu007@yahoo.com

Conflict Studies Quarterly

Issue 20, July 2017, pp. 34-55

DOI:10.24193/csq.20.3

Published First Online: 2017/07/3 
the involvement of volunteer vigilantes in counter-insurgency operations of the state. Available literature on the subject matter has yielded two dominant perspectives: while some analysts have maintained the cynical view that such an engagement is either symptomatic of the failure of the Nigerian state in terms of security provisioning, which has invariably necessitated the role of civil groups in filling the gap (Odomovo, 2014; HRC, 2015; Matfess, 2016), the rest hold the position that it is indicative of a functional civilmilitary synergy dictated by the imperative of anti-terrorism (Amnesty International, 2015; Stovenson, 2015).

This paper explores and evaluates the afore-mentioned analytical standpoints with a view to situating the rationale for the involvement of volunteer vigilantes in counterinsurgency operations in North-East Nigeria, as well as underscoring the strategic efficacy and implications of such approach to counter-insurgency vis-à-vis sustainable peace and stability in the region.

Essentially, the paper is concerned with providing answers to the following questions:

i. What is the rationale for the involvement of volunteer vigilantes in counter-insurgency operations in North-East Nigeria? Does that indicate a desperate resolve to community self-defence in the face of public security failure or a tactical civilmilitary synergy in response to the exigency of insurgency?

ii. What is the strategic efficacy and implication of this counter-insurgency approach vis-à-vis sustainable peace and stability in North-East Nigeria?

In tandem with the above, the paper seeks to achieve the following objectives:

i. To evaluate the rationale for the involvement of volunteer vigilantes in counterinsurgency operations in North-East Nigeria.

ii. To underscore the strategic efficacy and implication of such counter-insurgency approach vis-à-vis sustainable peace and stability in North-East Nigeria.

The paper is premised on the proposition to the effect that the involvement of volunteer vigilantes in counter-insurgency operations in North-East Nigeria is a circumstantial imperative, whose process tends to have been fraught with inconsistent and contradictory outcomes that negate sustainable peace and stability. This translates thus:

i. The exigency of community self-defence in the face of terrorism tends to have necessitated the involvement of volunteer vigilantes in counter-insurgency operations in North-East Nigeria.

ii. The involvement of volunteer vigilantes in counter insurgency operations in NorthEast Nigeria tends to have yielded both productive and counter-productive outcomes with dicey implications for sustainable peace and stability.

The paper is a product of an incremental research that was conducted in the focal study area between March and May, 2016. The research explored both anecdotal and 
empirical narratives through key informant interviews and field discussions. The outcome of the field study was complemented with relevant secondary data with a view to triangulating the analysis. The remainder of the paper is structured under the following themes: perspectives of civil volunteerism, vigilantism and volunteer vigilantism, setting the context of the study, overview of Boko Haram insurgency in North-East Nigeria, forms of vigilantes involved in counter-insurgency in North-East Nigeria, evaluation the strategic efficacy and implications of the involvement of volunteer vigilantes in counter-insurgency and conclusion.

\section{Volunteerism and Volunteer Vigilantism: Conceptual and Theoretical Analysis}

A volunteer is a person who works for an organisation or a group without the motive of being remunerated. In this wise, Selbee (2004) has defined volunteerism as including "any activity where unpaid work is provided to a formal organisation or group" (p. 19). Generally, volunteerism/volunteering has been conceived of in the existing literature from three fundamental perspectives, (i) as a component of charitable behavior and (ii) as a component of productive work in society (Selbee, 2014).

As a charitable behavior, volunteerism is concerned with the activities of individuals involved in providing assistance to others in need of social goods and services; as a civic engagement, it involves the participation of citizens in the maintenance of communities and more generally in the governance of society; as a productive endeavor, it refers to the provision of unpaid work (goods and services) that otherwise would not be as readily available in society (Selbee, 2004; Wu, 2011; Nielsen, 2013).

There are two important types of volunteering, namely short-term and long-term volunteerism. Short-term volunteering is episodic and short-lived while long-term volunteering is more or less extensive and institutionalized (Graff, 2002). Volunteerism emerged as an institutionalized form of development work in the context of the post-second World War societal reconstruction and rehabilitation.

The notion of volunteer vigilantism presupposes volunteering in the context of civil vigilantism. Vigilantism, simply put, refers to the "assumption of responsibility for community safety and values by self-appointed custodians prepared to use lethal force" (Haefele, n.d., p. 1). The concept of vigilantism is derived from the Spanish word 'vigilante', which literally translates to 'watchman' or 'guard' (Haefele, n.d; Newby, 2012). Vigilantism is characterized by 'lethality', 'autonomy' and extra-legality (Greenberg, 2005; Jarman, 2007). In effect, vigilante formations apply lethal force, operate without the explicit support or authority of the state and adopt extra-lethal methods (Jarman, 2007).

Vigilantes have been classified based on certain characteristics. Sederberg's (1978) typology identifies four modes of vigilantism, namely: (i) private spontaneous vigilantism, (ii) private organized vigilantism, (iii) official spontaneous vigilantism and (iv) official 
organized vigilantes. Vigilantes have also been classified as ethnic, religious, communal, corporate, civil, etc. (Alemika \& Chukwuma, 2004). The notion of volunteer vigilantism interrogated herewith fits into the conceptual schema of civil vigilantism. This pattern of vigilantism is peculiar because, in addition to enjoying states' overt authorization, it has appreciably bolstered the endeavors of the state forces in the counterinsurgency campaign operations.

There exists an avalanche of literature on the nature, purpose, uses, abuses, as well as challenges and prospects of vigilantism as a mode of civil security provisioning in contemporary societies. One of the prominent perspectives in existing literature regarding the essence of vigilantism is that it signifies 'privatization of security' and, therefore, de-monopolization of force by the state (Berndtsson, 2009). According to Berndtsson (2009), privatization of security refers to the emergence of 'non-state actors specializing in protection, including armed protection in conflict zones and sometimes even active engagement in combat operations'. Understanding the emergence of vigilantism from the standpoint of 'privatization of security' implies that it marks a departure from the tradition of military monopoly to that of civil-military synergy in terms of control and use of force. This resonates with the 'civilianization of security' perspective of civil vigilantism. The notion of 'civilianization of security' has been aptly conceived as:

... relating to non-military, voluntary organizations and the business/private sector engaged by government but acting in their own right to prevent, protect, and prepare in the context of counterterrorism. It is a phenomenon by which ordinary civilians act as providers of their own security in a specific new kind of war, that is, war against terrorism (Sliwinski, 2013, pp. 14-15).

Indeed, the exigencies of counter-terrorism in the contemporary world have mandated a new pattern of civil-military relations that reflects the logic of 'civilianization of security' (May, 1992; Azarbajiani-Moghaddam, Wardak, Zaman, \& Taylor, 2008; Horton, 2014). This is instantiated in the increasing involvement of the civil society in counterterrorism operations and intelligence. The role of volunteer vigilantes in the context of counterinsurgency in North-East Nigeria depicts this trajectory, although the trend has been bolstered by the increasing helplessness of the Nigerian state in protecting communities from the onslaught of insurgency in the region, which has necessitated a resort to self-defence.

The bulk of contemporary literature on community policing in Africa recognizes vigilantism as a veritable approach (Baker, 2002, 2008; Alemika \& Chukwuma, 2004; Kyed, 2009; Mbogo, Ndung'u, Campbell, \& Rai, 2008; Onwudiwe, 2009; Okeke, 2013). In these literatures, the phenomenon of vigilantism has been variously described, or alluded to, as 'informal policing', 'voluntary policing', 'alternative policing', 'private policing', or 'multi-choice policing'. Scholarly views are, however, divided as regards the legitimacy and/or legality of such security arrangements. While some analysts believe that vigilan- 
tism is tantamount to usurpation or erosion of the state's monopoly of violence, others contend that it is an indication of security sector reforms in the world characterized by volatile security dynamics (Berndtsson, 2009; Fourchard, 2011). There is, nonetheless, a seeming consensus to the effect that the rising currency and saliency of vigilantism as a mode of 'alternative policing' (Baker, 2008) stem essentially from the failure of the state in living up to its security functions (Kantor \&Persson, 2010; Jarman, 2007; Newby, 2012). As Fourchard (2011) poignantly puts it, "people's discontents about inequality, corruption and injustice have fuelled throughout the $20^{\text {th }}$ century alternative solutions to state policing" (p. 4).

Contemporary expressions of vigilantism in Africa represent, in varying dimensions, a reincarnation of the traditional systems of communal guardship (HRW/CLEEN Foundation, 2002; Fourchard, 2011; Okeke, 2013). In its modern state, vigilantism in the continent has evolved into a civic movement, representing either civil or primordial interests. In effect, there exists a variety of ethnic, religious, corporate, communitybased and state-sponsored vigilantes in different parts of Africa (ACCORD/UNHCR, 2002; Alemika \& Chukwuma, 2004; Okeke, 2013).

With reference to Nigeria, a number of vigilante types have been identified by scholars (HRW/CLEEN Foundation, 2002; Fourchard, 2011; Okeke, 2013). This is reflected in the typology shown in table 1.

Table 1: Typology of Vigilantism in Nigeria

\begin{tabular}{|c|c|}
\hline Primordial Types & Civil Types \\
\hline $\begin{array}{l}\text { 1. Ethnic vigilantes (e.g. the Odua People's } \\
\text { Congress (OPC) in Western Nigeria. } \\
\text { 2. Religious vigilantes (e.g. the HisbaShar'ia } \\
\text { Force in some northern states of Nigeria. } \\
\text { 3. Communal vigilantes (e.g. various tradition- } \\
\text { al vigilantes groups in local communities. }\end{array}$ & $\begin{array}{l}\text { 1. Corporate vigilantes (e.g. registered private } \\
\text { security custodians). } \\
\text { 2. State-sponsored vigilantes (e.g. the Civilian } \\
\text { Joint Task Force (CJTF) in North East Nige- } \\
\text { ria. } \\
\text { 3. Mercantile/mercenary vigilantes (e.g. the } \\
\text { Bakassi Boys (vigilante) hired by some } \\
\text { South-eastern states in early 2000s to fight } \\
\text { crime and social vices. }\end{array}$ \\
\hline
\end{tabular}

Source: Authors' compilation.

Operationally, vigilantism has been associated with some negative outcomes, which have questioned its efficacy as an alternative security framework. A case in point is the incessant friction or rift between the operatives of formal security agencies and members of vigilante groups (Barkindo, 2007; Enechojo, 2013). There have also been cases of gross human rights abuse occasioned by the operational excesses of the vigilantes (Alemika \& Chukwuma, 2004; McCall, 2004). This tendency has been observed in respect of the activities of the Bakassi Boys and the Hisba vigilante formations in Nigeria (HRW/CLEEN Foundation, 2004; International Crisis Group, 2010; Dogarawa, 
2011). The involvement of vigilantes in extra-legal killings, extortion, rape, excessive use of force, and unprovoked brutality tends to have validated Brown's (1975) assertion that vigilantism is 'organized extra-legal movements, the members of which take laws into their own hands' (cited in Greenberg, 2005, p. 5).

\section{Situating the Context of Analysis: Profile of North-East Nigeria}

Although incidents of Boko Haram insurgency have been widely reported in NorthCentral and North-Western Nigeria, the focal flash-bed of the incidence has remained the North-East (Okoli \& Iortyer, 2014). This section presents a descriptive overview of North-East Nigeria as well as Boko Haram insurgency in that context, with a view to casting the general setting and contextual background of the paper. In addition, the section attempts a review of counterinsurgency endeavors in the region under reference and underscores the imperative and rationale for civilian involvement.

3.1. North-East Nigeria: Nigeria is a federation of thirty-six states. For political convenience, dictated by the logic of 'federalist structuring' (Okoli \& Okpaleke, 2013), these states have been sub-divided into six geo-spatial extractions popularly known as 'six geo-political zones of Nigeria'. The six zones alongside their constituent states are shown in table 2.

Table 2: Six 'Geo-political' Zones of Nigeria

\begin{tabular}{|c|c|c|c|}
\hline Zone & Constituent States & Zone & Constituent States \\
\hline \multirow{6}{*}{ North-Central } & 1. Benue & \multirow{5}{*}{ South-East } & 1. Abia \\
\hline & 2. Kogi & & 2. Anambra \\
\hline & 3. Niger & & 3. Ebonyi \\
\hline & 4. Kwara & & 4. Enugu \\
\hline & 5. Nasarawa & & 5. Imo \\
\hline & 6. Plateau & \multirow{6}{*}{ South-South } & 1. Bayelsa \\
\hline \multirow{6}{*}{ North-East } & 1. Adamawa & & 2. Delta \\
\hline & 2. Bauchi & & 3. Akwa-Ibom \\
\hline & 3. Borno & & 4. Cross-River \\
\hline & 4. Gombe & & 5. Edo \\
\hline & 5. Taraba & & 6. Rivers \\
\hline & 6. Yobe & \multirow{8}{*}{ South-West } & 1. Ekiti \\
\hline \multirow{7}{*}{ North-West } & 1. Jigawa & & 2. Lagos \\
\hline & 2. Katsina & & 3. Ogun \\
\hline & 3. Kaduna & & 4. Ondo \\
\hline & 4. Kano & & 5.0 yo \\
\hline & 5. Kebbi & & \\
\hline & 6. Sokoto & & \\
\hline & 7. Zamfara & & \\
\hline
\end{tabular}

Source: Author's compilation. 
North-East Nigeria comprises six states, namely Adamawa, Bauchi, Borno, Gombe, Taraba and Yobe (Table 1 above). The region is a coalescence of a multiplicity of sociocultural categories. Historically, three dominant civilizations festered in the region. They included the Kanem-Bornocivilization, the Hausa-Fulani civilization and, to a lesser extent, the Kwararafa civilization (Ngare, 2012).

North-East Nigeria is characterized by immense ethnic-cum-linguistic diversity and heterogeneity. Apart from hosting the dominant ethnic categories of Kanuri, HausaFulani, Jukun, Bachama, Mumuye, etc. the region is also home to a multiplicity of other ethnic and sub-ethnic groups. In terms of religious identity and affiliations, the region has a strong expression of Islam, Christianity and African Traditional religions (ATR).

According to the official figures of the 2006 population census in Nigeria, close to twenty million people live in Northeastern Nigeria (NPC, 2006). This includes the population of both the native and migrant communities in the various parts of the region. Table 3 shows the population distribution across the states of the region based on the 2006 census.

Table 3: Population of the States of Northeastern Nigeria from 2006 Population Census

\begin{tabular}{lc}
\hline \multicolumn{1}{c}{ State } & Population \\
\hline Adamawa & $3,178,950$ \\
Borno & $4,171,104$ \\
Bauchi & $4,653,066$ \\
Gombe & $2,365,040$ \\
Taraba & $2,294,800$ \\
Yobe & $2,321,339$ \\
\hline
\end{tabular}

Source: National Population Commission (NPC, 2006), Abuja, Nigeria.

The topography of the North-East Nigeria is varied and versatile. It consists of a mix of high and low lands interspersed by rivers, floodplains valleys, cliffs, hills and mountains, forests and lakes. The dominant vegetation of the region is savannah with semi-arid conditions in the Sahel axis of Borno and Yobe. However, the southern axis of the region, particularly Taraba state, has peculiar 'woods-and-wilds' vegetation. Overall, the climatic conditions of the North-East are essentially hazardous. There is a high incidence of weather-related adversities, exemplified in the prevalence of desert-encroachment, drought and wind storm (Okoli, 2014).

3.2. Overview of Boko Haram Insurgency in Northeastern Nigeria: Boko Harma refers to an extremist Islamic sect formerly known as Jama'aAhl as-Sunna Lida'wa-al Jihad. It emerged in the early 2000 s as a small Sunni Islamic sect advocating strict implementation and interpretation of the Islamic law in Nigeria (Congressional Research 
Service, 2016). The group was originally led by Mohammed Yusuf, a radical Islamic cleric, who was killed in police custody in 2009.

Prior to Yusuf's murder, Boko Haram members had engaged in periodic skirmishes with the Nigerian police, particularly in the Northeastern States of Borno and Yobe. Following the killing of Yusuf in 2009, the group was further radicalized and, therefore, re-mobilized for violence (Okoli \& Iortyer, 2014). Subsequently, the group engaged in isolated hard-target attacks, hitting police stations, military formations, government institutions and public infrastructures. The group carried out jail breaks and series of attacks on police/military checkpoints in this era. In 2011-2013, Boko Haram fighters resorted to the use of improvised explosive devices (IEDs) to attack both soft and hard targets. In this process, several churches and schools were attacked leading to multiple casualties (Amnesty International, 2014). Sequel to this, a state of emergency was declared on the Northeast States of Borno, Adamawa and Yobe by the Federal Government of Nigeria in 2013.

By 2014, Boko Haram attacks on civilians had escalated. Consequently, many worship places (churches and mosques alike), commercial motor vehicle parks, markets, recreational centers and other crowded places were attacked by the insurgents. By mid2014, Boko Haram launched a tactical change from their regular asymmetric war to coordinated offensive geared towards seizing and holding territories. And only a couple of weeks after, the group declared an Islamic Caliphate in North-East Nigeria. Since the first quarter of 2015, there has been drastic reduction in the scale and frequency of Boko Haram violence in Nigeria owing, partly, to the involvement of neighboring countries and volunteer vigilantes in the re-strategized counterinsurgency campaign led by the Nigerian military (personal communication, Abuja, May 31, 2016).

The impact of Boko Haram insurgency on the people, economy and culture of North-East Nigeria has been dire. From the standpoint of its humanitarian consequences, it has been noted that Boko Haram insurgency has been a veritable threat to human security in the affected States (Okoli \& Iortyer, 2014). Recent records reveal that:

More than 15,000 people are estimated to have been killed by Boko Haram, including more than 6,000 in 2015 alone. By UN estimates, roughly 2.8 million people have been displaced by Boko Haram related violence in the Lake Chad Basin region, where approximately 5.6 million are in need of emergency food aid (Congressional Research Service, 2016, p.i).

The implication of the above is that Boko Haram insurgency poses a critical threat to the national security and sustainability in Nigeria. The need to mitigate this threat has over the years informed the adoption of a variety of counterinsurgency mechanisms, including the resort to volunteer vigilantism. 
Box 1: Timeline of Boko Haram Violence

\section{Selective Chronology: 2003-2017}

2003 - Boko Haram established in northern Nigeria under the leadership of Islamic cleric Mohammed Yusuf. Yusuf preached that the country's ruling was marred by corruption and advocated for the creation of an Islamic state.

July 2009 - Boko Haram members clashed with security forces in several northern states, resulting in at least 800 deaths. Mohammed Yusuf was arrested and killed in police custody.

2010 - Boko Haram regroups and starts its campaign of violent attacks against security forces, schools, churches and civilians.

September 2010 - Boko Haram attack a prison in Bauchi State, freeing 150 of its members and several hundred other prisoners.

12 June 2011 - The Nigerian government established a Joint Task Force (JTF) in Borno state, to 'restore law and order' to North-East Nigeria. It is comprised of personnel from the Nigerian Armed Forces, the Nigeria Police Force (NPF), the Department of State Security (DSS), the Nigerian Immigration Service (NIS) and the Defence Intelligence Agencies (DIA).

16 June 2011 - Boko Haram bombs Nigeria's National Police Force Headquarters in Abuja.

26 August 2011 - Boko Haram bombs the UN offices in Abuja, killing 23.

26 April 2012 - Boko Haram bombs the offices of the Nigerian newspaper Thisday in Abuja and a building housing three news papers, including This Day, in Kaduna. At least seven people died.

November 2012 - The Prosecutor of the International Criminal Court notes that serious human rights violations may have been committed by the JTF and that Boko Haram's attacks may constitute crimes against humanity.

May 2013 - President Jonathan declares a state of emergency in Adamawa, Borno and Yobe states, which is rapidly approved by the National Assembly.

May 2013 - A vigilante group, known as 'civilian joint task force', is formed with government support in Maiduguri. They are given powers to arrest suspected Boko Haram members and hand them over to the security forces.

November 2013 - The National Assembly approves a 6-month extension to the state of emergency in Adamawa, Borno and Yobe states.

2014 - Attacks by Boko Haram against civilians intensify, becoming an almost daily occurrence. The JTF responded by increasing its campaign to flush Boko Haram out of its camps in the east of Borno state.

16 January 2014 - President Jonathan replaces the Chief of Defence Staff and other senior military figures.

14 March 2014 - Boko Haram attacks the Giwa military barracks in Maiduguri, allegedly freeing over one thousand inmates. The military re-captured the barracks, then rounded up and shot hundreds of escaped detainees.

April 2014 - Abduction of nearly 300 girls from a school dormitory in Chibok

July 2014 - Boko Haram shifts from asymmetric attacks to a conventional offensive dedicated to seizing and holding territory.

August 2014 - Boko Haram declares an Islamic state in Northeast 
7 March, 2015 - Boko Haram pledged allegiance to ISIS

April 2015 - Boko Haram began to lose most of its territories, sliding into the Sambisa forest. December 2016 - Nigerian military began intensive combat operations in Sambisa forest in an attempt to recapture the territory and dislodge the insurgents

May 2017 - Some girl-captors (Chibok girls) were released by the insurgents in exchange for some of their commanders

Source: Adapted from Amnesty International (2014, p. 5); additional information from Congressional Research Service (2016, p. 5); also, author's update.

3.3. The need for civilian intervention: Contemporary trajectories of terrorism/insurgency world over indicate that civil population has become the centerpiece of terrorist attacks. This underscores the fact that counterinsurgency in this era must recognize the imperative for "investment in civilian modes of warfare" (Bell, 2011, p. 309). Nigeria's counterinsurgency campaign started with heavy reliance on the military approach. The principal limitation of this approach was that the military was helpless at eradicating insurgents' cells and structures which were increasingly infiltrating the civil population in both urban and rural areas (personal communication, Abuja, May 31, 2016).

Following the declaration of the state of emergency in Borno, Adamawa and Yobe States in 2013, there was a dramatic escalation of hostilities between the government forces and Boko Haram insurgents, with the civil population being at the receiving end (Amnesty International, 2014). Amidst this crisis, there was a compelling need for the involvement of the affected communities in prosecuting the counterinsurgency crusade. The military needed the assistance of the locals to defend their communities and communal heritage from the activities of the insurgents. Banking on their mutual goodwill, the military and various community vigilantes started collaborating in an attempt to defeat the common enemy-Boko Haram (AOAV, 2012).

Suffice to note, therefore, that the emergence and involvement of volunteer vigilantes in the fight against insurgency in North-East Nigeria was a child of necessity. As an observer succinctly opined, 'it is a case of civilian-military uprising against the insurgents' (personal communication, Maiduguri, May 23, 2016). Indeed, it is an existential struggle for survival in a hostile and volatile environment wherein the communities have resolved to rise up to the challenges of their time and collectively defend their destiny (Anyadike, 2014).

Available literature suggest that the rise of anti-Boko Haram vigilantes in North-East Nigeria was necessitated by the need for the civilians to protect themselves amidst the apparent inability or failure of the government forces to guarantee their security. In this regard, Watch List (2014) notes that "self-defense forces have become widespread in North East Nigeria as civilians have taken up arms against JAS (Boko Haram) to defend their communities, filling a security void left by the government security forces" (p. 27). 
Similarly, the Human Rights Council (HRC) in its official report opines:

The inability of security forces to protect civilians from Boko Haram attacks and the deterioration of the security situation have led to the emergence of local self-defense groups, known as vigilantes in North East Nigeria and Cameroun (2015, p. 13).

It can be thus submitted that the involvement of volunteer vigilantes in counterinsurgency endeavors in Nigeria's North-East is a consequence of "shortcomings in the Nigerian system of governance", whereby vigilantes forces have arisen to fill the obvious "legitimate security gaps" (Matfess, 2016, pp. 8-9).The prevalence of Boko Haram onslaught and the apparent inability of the government to contain the situation have driven the inhabitants into taking up arms in self-defence against their adversaries. The nature and strategic implications of this engagement are considered in the subsequent sections.

\section{Vigilante Actors in Counterinsurgency Operations in North East Nigeria}

Following the escalation of Boko Haram insurgency in North-East Nigeria, local communities in the affected areas resorted to forming informant networks and self-defence mechanisms in order to protect themselves from the machinations of the insurgents. Some of these initiatives were spontaneous and improvised while others were built upon extant local/customary vigilante frameworks. In all, three modes of such initiatives have emerged, namely (i) communal neighborhood guards, (ii) the local hunter's guild and (iii) the civilian Joint Task Force (CJTF). These models of community-based anti-Boko Haram vigilantism are discussed in turn below.

4.1. Neighborhood guards: Neighborhood guards are customary community policing system in most parts of the North-East. In the context of Boko Haram crisis, various communities in the region repositioned the existing neighborhood guard structures in order to brace up to the rising threat. Some ad-hoc arrangements that were essentially spontaneous also emerged in that context.

The purpose of neighborhood guards is to protect their communities from possible Boko Haram infiltration and attacks. They conduct native espionage, community patrol, nightvigil and general community policing. They also operate community-wide informant networks, as well as threat-alert system. The structure of neighborhood guards varies from one community to another. They are characterized by lose command system and fluid membership. Their leadership and control is often tied to the community authorities. In some cases, however, leadership and control is personalized by a self-made local warrior at whose behest the structure exists. Membership is largely voluntary and parttime. Operators of neighborhood guard systems bear rudimentary arms and protective amulets. They are often believed to be bestowed with some supernatural powers that make them indestructible. In most cases, they observe some fetish practices by which they claim to renew their potency. Various patterns of communal neighborhood guard 
systems have been in operation in the hinterlands of Borno, Yobe, Gombe, Adamawa, and Taraba states. Since 2013, following the emergence of the hunter's guild and the CJTF, some members of the neighborhood guard systems have been defecting to the new platforms (personal communication, Mubi, May 24, 2016).

The activities of the neighborhood guards in the context of counterinsurgency in NorthEast Nigeria have not been consciously documented. Local narratives and anecdotes, however, suggest that they have been instrumental in protecting local communities from the infiltration of the insurgents. A key informant in Adamawa opined that they have worked in close liaison "with the community leadership and the government forces in identifying and arresting suspected insurgents" (personal communication, Mubi, May 24, 2016).

It is not clear from available sources if the activities of this group have been arbitrary or extra-judicial. Suffice it to note that they have been accused of highhandedness in some cases.

4.2. Local hunters: Local hunters have been in the forefront of the campaign against Boko Haram insurgency. These groups have been replicated in many states, including Gombe, Bauchi, Adamawa and Yobe, to protect communities from further attacks and to apprehend suspected Boko Haram members (Dietrich, 2015).

The local hunters comprise able-bodied male and women who have volunteered to assist the government forces in the military campaign against the Boko Haram insurgents. The group emerged in Adamawa state in 2014 when a number of hunters came together with a resolve to donate their skills and expertise to the government's counterinsurgency operations. The hunters are armed with rudimentary weapons: Dane guns, bows and arrows, machetes and amulets. Unlike the communal neighborhood guards, the local hunters are involved in both defensive and offensive counterinsurgency.

Currently, the local hunters are found in varying degrees in all States of the North-East. They number over ten thousand in all but are mostly concentrated in Adamawa and Yobe States (Today, 2016). In Adamawa state, they are reputed to be the arrow-head of the operations that led to the rescue of Gombi, Mubi and Maiha area from the territorial occupation of Boko Haram insurgents (personal communication, Mubi, May 24, 2016). Hence, the hunters, otherwise known as 'Yan Baka' in local Hausa parlance, have been quite effective in containing the invasion of insurgents in the country sides of the state.

In Yobe State, there exists a brand of local hunter's called the 'the Mahaba'. Membership of Mahaba consists of native hunters who inherited the trade of hunting from their ancestors (personal communication, Gashua, May 25, 2016). Commenting on the efficacy of the Mahaba, a key informant interviewed in Yobe State opined:

Mahaba.... are more proactive because they possess the wizardry to tame their local environment and protect it from infiltrators. Thus, they have been 
helpful in the fight against the insurgents in the North east. Specifically, it was this group of hunters that drive (sic) away the Boko Haramists (sic) in Bade areas of Yobe State and rendered their activities null (personal communication, Gashua, May 25, 2016).

The local hunters in the North-East have evolved into a sort of local para-military association with a fairly defined and established leadership-cum-command structure. The leadership of the association liaises with CJTF and the military in ensuring that there is a united front against the insurgents. Their activities have paid off in States such as Yobe and Adamawa. Today, the activities of the local hunters are operationally coterminous with those of the CJTF. In effect, some of the members of the hunters' association are being co-opted in the mainstream of the CJTF.

4.3. The civilian JTF: Civilian JTF stands for Civilian Joint Task Force (CJTF). Otherwise known in local parlance as 'Kato Da Gora', translating literally as 'Man with a stick', CJTF emerged in 2013 in Maiduguri, Northeastern Nigeria, as a self-help/self-defence interest group dedicated to counterinsurgency (Human Rights Council, 2015). Tracing the origin and emergence of CJTF, Hassan (n.d.) notes that:

The ragtag civilian Joint Task Force (CJTF) comprising Bornu Youth started in May 2013 in Maiduguri when Baba LawanJafar, the overall chairman of the 'Civilian JTF' in Borno State, fearlessly chased and captured a gunman with only a stick and handed him over to the men of the Joint Task Force (JTF), Operation Restore Order. This impressive act led one Modu Milo to join Jafar in the hunt and eventually led to the emergence of the Civilian Joint Task Force as actors in curbing the on-going insurgency in the North East Nigeria (p. 1).

The emergence of the CJTF was buoyed by the self-help resolve of the youths to identify with the military forces in redeeming their communities from the onslaught of Boko Haram insurgency in the aftermath of the declaration of the 'state of emergency' in the Northeast in 2013. Concerning this development, Odomovo (2014) avers:

Since the declaration of a state of emergency in the North East states of Adamawa, Borno, and Yobe on 14 May, 2013, the violent conflict in Maiduguri, the Borno state capital has taken a different dimension. Bands of youths brandishing dangerous weapons such as cutlasses, knives, swords, sticks, axe, cudgels, bows and arrows, have appeared on the streets of Maiduguri... these are member of the Borno Youth Vigilante Group who have emerged to assist the official JTF deployed to curb the menace of Boko Haram insurgency in the state. The youth vigilante group is popularly known as Civilian JTF because the group has the implicit endorsement of the official JTF (p. 55).

Members of the CJTF consist of "boys and men aged between 14 and 30" (Amnesty International, 2015, p. 24). The CJTF assist the government forces with identifying and arresting Boko Haram suspects, controlling security checkpoints, providing information, 
monitoring the movement of people, and the like (Amnesty International, 2014). It has "also used fire arms against Boko Haram in self-defence and to safeguard communities" (Human Rights Council, 2015, p. 14).

Recruitment into the CJTF is ostensibly voluntary, although there have claims of forced and child recruiting (Amnesty International, 2014; Human Rights Council, 2015). It is difficult to estimate the numerical strength of the CJTF; this is because some of its members are undocumented and/or unregistered. It is, nonetheless, suggested that the group number over 2000 , with $1,400-1,500$ of them registered and paid by the state authorities (Amnesty International, 2015, p. 25).

The registered members of CJTF are entitled to a monthly allowance facilitated by the State governments of Borno, Yobe and Adamawa (Burchard, 2014; Watch List, 2014). Although the activities of the CJTF remain largely unregulated, they have, by and large, operated under the military command (Amnesty International, 2015). The CJTF organizes itself into neighborhood 'sectors' superintended by the sector commands of the official JTF. In this sense, the CJTF is operationally subjected to the military oversight and command ship (International Crisis Group, 2014).

The CJTF has been trained and has often been equipped with arms by the military. They have collaborated with the military in a number of operations both as front-liners and support agents (International Crisis Group, 2014). Their activities have been associated with some operational exploits as well as abuses/excesses. Whereas they have been a dependable ally to the military in confronting and degrading the insurgents, they have often been accused of highhandedness and sundry abusive behaviors as highlighted in the next section. Box 2 provides additional insights on the nature and operations of the CJTF.

Box 2: Overview of the CJTF

The 'Civilian JTF', loosely organized vigilantes, was set up in 2013 in Maiduguri, Borno state to work with the Nigerian security forces to restore normalcy to the state. Their primary responsibility, according to security and government officials, is to identify and help arrest suspected Boko Haram members. There are consistent reports of human right abuses by the civilian JTF. The name 'Civilian JTF' is being used to show the association between the JTF (comprising the Nigerian army, Police and State Security Services) and the civilians who have volunteered to serve as vigilantes in the fight against Boko Haram.

The group of vigilante emerged after President Goodluck Jonathan declared a State of Emergency in Adamawa, Borno and Yobe state in May, 2013. Initially, it had no command structure. It was not established by law and has no known Code of Conduct. As the months progressed, however, selected individuals were made 'commanders' and 'area coordinators'. Members of the 'Civilian JTF" are supervised by Nigerian security forces. They give information and hand over Boko Haram suspects to the security forces (otherwise known as JTF). Several hundreds have been trained by the authorities. According to local sources, they receive allowances. There is known recruitment procedure.

Source: Amnesty International (2014, p. 12). 


\section{Vigilantes and Counterinsurgency: Evaluating the Strategic Efficacy and Implications}

Volunteer vigilantes have proved effective in the fight against insurgency in Nigeria. In a paper related to the subject matter, Stovenson (2015, p. 18) surmises that:

i. vigilantes have been the most effective vehicle at disrupting the ability of Boko Haram to execute terrorist attacks;

ii. combined vigilante and military operations have reduced whatever increased risk that military operations cause concerning the probability of a (escalated) terrorist attack;

iii.joint police-vigilante operations holds the greatest prospect of containing Boko Haram insurgency.

In spite of the above positive observations, Stovenson reserves misgivings to the effect that mindless and unregulated deployment of vigilante groups in counterinsurgency could be counter-productive in the long run. He thus alarms (2015):

While vigilantes groups may be important in the short term in disrupting Boko Haram activities and serving as local partners in a successful counter terrorism strategy, arming militias are likely not a long term policy especially if one wants to avoid unintended consequences (p. 19).

The unintended consequences referred to in the above citation can be varied. For instance, owing to the fluid and 'un-regimented' structure of the vigilantes, the problems of discipline, accountability and infiltration have often arisen (Gaffey, 2015). This has often resulted in operational abuses and excuses on the part of the members of the vigilantes. In this regard, it has been observed that:

While the role of the vigilantes in counterinsurgency operations is appreciated among the military and civilian population, there is a growing concern about the excesses of some members of the CJTF and vigilante groups. During the month, there were reports of rising incidents of clashes between IDPs and CJTF in IDP camps in Borno State. One of such clashes in Shettima Ali Monguno village camp resulted in the death of a man. The clashed have been attributed to allegations of involvement of the vigilantes in extortion, sexual and gender based violence and human rights violations (NSRP, 2016, p. 3).

There have also been allegations of forced recruiting, child and woman soldiering, extrajudicial killings and suspected insurgents, and other human rights abuses (Congressional Research Service, 2016). This is in addition to the palpable fears that the vigilante groups may metamorphose into mercenary militias that may be used to advance the cause of ethno-communal, religious and political conflicts (Hassan, n.d.; Stovenson, 2015). Akin to this is the issue of armed proliferations, which can also result from possible eventual misapplication of weaponry by the combatant vigilantes. 
Further to the issue of abuses, there has also been the unintended outcome of violent reprisals orchestrated by the insurgents in vengeance for the vigilante attacks on them. This form of retaliatory attacks has often been targeted on communities that identify with the volunteer vigilantes. As Odomovo (2014) succinctly puts it:

On several occasions some of the youths (vigilantes) have been ambushed and killed by Boko Haram insurgents. For example, in July 2013, member of the civilian JTF invaded the villages of Mainok and Dawashi in Maiduguri in search of insurgents. Following the invasion, Boko Haram insurgents killed about 43 members of the vigilante in a fierce retaliatory attack (p. 55).

The retaliatory attacks have also been targeted against the structures of the vigilantes. For example, the insurgents struck the local vigilante office of Nangare, Gashua in Yobe State on $15^{\text {th }}$ June, 2015 , killing six people and injuring several others in a bomb attack (WANEP-Nigeria, 2015). Those interviewed in the course of this paper confirmed similar occurrences in parts of Borno, Gombe and Adamawa States.

There have equally been cases of infiltration by the insurgents into the rank and file of the vigilantes. Those interviewed during the research made reference to such infiltrations. There was a popular media report of a middle-aged man in Bama area of Borno Sate, who pretended to be working for the CJTF, but later sold out the operations of the group to the insurgents. It was gathered via local narratives and anecdotal sources that such mishap accounted for the bulk of the incidents where the vigilante forces were ambushed and massacred. Similar cases were reported in Damboa, Mainok and Dawashi in the hinterlands of Borno State where suspected vigilantes and their sympathizers were killed in cold blood by the insurgents in retaliatory ambushed attacks (Odomovo, 2014). The loose organizational structure and leadership of the vigilantes makes susceptible to infiltration and internal sabotage. The worst contradiction associated with the role of volunteer vigilantes in counterinsurgency operations in North East Nigeria is the tendency for the operators to indulge in 'jungle justice'. As observed by Odomovo (2014):

The vigilante groups sometimes take law into their own hands by... arresting suspected insurgents including innocent civilians. As part of their efforts in fishing out Boko Haram insurgents, these youths often dispense justice to their victims in a jungle manner (p. 55).

Their excesses notwithstanding, volunteer vigilantes have proved to be a veritable and functional partner of the military in the fight against insurgency in North East Nigeria. With their proper understanding of the operational terrain of counterinsurgency, the vigilantes have assisted the military in identifying and overriding important structures of the insurgents through local intelligence and reconnaissance. They have also facilitated arrests of high-profile Boko Haram suspects, as well as the rescue of some of their 
abductors. It is to their credit that the historic rescue of one of the abducted Chibok girls was made on May 18, 2016.

The relative success of the vigilantes in counterinsurgency in North-East Nigeria affirms the underlying thinking in 'societal/human security' literature that security is best provided by the people and not for the people (Hassan, n.d., p.1; Afeikhena, n.d.; ETTIS, 2012). As the experience in North-East Nigeria tends to justify:

Charging locals with protecting their own communities becomes imperative, because they are well acquainted with the terrain under (sic) which they operate against the troops deployed who are often language-challenged; have little or no knowledge of the different arid terrain or territory... (Hassan, n.d., p. 2).

The apparent successes of volunteer vigilantes in the fight against Boko Haram insurgency has been acknowledged by many observers, including the government and the military (International Crisis Group, 2014). However, critics contend that these vigilantes operate illegally as ill-regulated armed groups. They also argue that, according to such groups, a front-line position in counterinsurgency operations portends that the state is abdicating her primary function to see to national security (International Crisis Group, 2014). In spite of these misgivings, the justification for vigilante approach in the fight against insurgency cannot be overemphasized. As observed by Burchard (2014):

Vigilante groups are uniquely poised to contribute to local security because these groups form in response to specific issues and conditions; are staffed by local volunteers who have knowledge of the community; and often have trust of the local community(n.p.).

\section{Conclusion}

Contemporary terror-insurgency is an asymmetric warfare that requires an equally unconventional remediation. The civilian intervention in counterinsurgency in North-East Nigeria reflects this strategic imperative. Amidst the lethal onslaught of Boko Haram insurgents against the communities of North-East Nigeria and the apparent helplessness of the state (the government and its security forces) in mitigating the situation, the inhabitants were faced with three unpleasant and dicey options: to flee their communities; to join the insurgent groups; or to be killed. In effect, while some inhabitants succeeded in fleeing to safer places, others were stuck in the volatile area where they were compelled to, indeed, either join the insurgents or be killed. Overtime, the people thought of the fourth option- mobilizing for self-defense based on self-help. They thus mobilized themselves into community vanguards poised to confront the machinations of the rampaging Boko Haram insurgents. This resolve marked the genesis of what is today known as Civilian Joint Task Force (CJTF) and its allied volunteer vigilantes.

The involvement of these vigilantes in counterinsurgency in North-East Nigeria marks a departure from the military-centric to civilian-oriented counterinsurgency opera- 
tions. Apart from policing their local communities, these volunteer vigilantes have been assisting the military in identifying, arresting and spying suspected insurgents. They have largely facilitated the major breakthroughs made by the military in terms of high profile arrests of suspected insurgents as well as rescue of their hostages. However, the activities of the volunteer vigilantes have been unfortunately associated with some untoward occurrences, such as human rights abuses, extortions, oppression, gang violence, sexual harassment, child/woman recruiting, forced recruitment and other extra-judicial excesses. More unfortunately, the vigilantes have often provoked retaliatory violence whereby the insurgents capitalize on their counter-attacks to raid communities that are associated or sympathetic with the vigilantes. These occurrences have smeared the efficacy of the involvement of these vigilantes in counterinsurgency in the area under review.

There is, therefore, a need to ensure that the vigilantes operate in a manner that forecloses untoward and counterproductive outcomes. First, they must seek to operate within the confines of the law. In this regard, the activities of the vigilantes should be properly coordinated and regulated through established legal and institutional procedures to forestall operational impunity. In this direction, the Federal Government of Nigeria needs to evolve coherent policy-cum-institutional mechanisms for harnessing the vigilantes, so that they can operate as authentic community policing system. Alternatively, the government should consider absorbing some of the organized vigilante formations into the existing paramilitary structures or institutionalizing them into a national reserve force amenable to emergency mobilization. It is the conviction of this paper that the aforementioned measures would go a long way in optimizing the potentials of volunteer vigilantes and at the same time modulating their excesses in the overall interest of national security of Nigeria.

\section{References}

1. ACCORD/UNHCR. (2002). Nigeria: Country Report by ACCORD/UNHCR at $8^{\text {th }}$ European country of origin information seminar, held at Vienna on 28-29 June.

2. Afeikhena, J. (n.d.). Lessons from Colombia for curtailing the Boko Haram insurgency in Nigeria. PRISM, 5(2), 95-105.

3. Alemika, E.E.O., \& Chukwuma, I.C. (2004). The poor and informal policing in Nigeria. A report on poor people's perceptions and priorities on safety, security and informal policing in A2J focal states in Nigeria. Lagos: CLEEN Foundation.

4. Amnesty International. (2014). Nigeria: More than 1,500 killed in armed conflict in North- Eastern Nigeria in early 2014. London: Amnesty International Publication.

5. Amnesty International. (2015). Stars on their Shoulders: Blood on their hands: War Crimes committed by the Nigerian military. London: Amnesty International Publication.

6. Anyadike, 0. (2014, August 11). Nigeria-the community turns against Boko Haram. IRIN.Retrieved from www.irinnews.org/news/2014/08/11. 
7. AOAV. (2012). The violent road: An overview of armed violence in Nigeria. London: Action on Armed Violence (AOAV).

8. Azarbajiani-Moghaddam, S., Wardak, M., Zaman, I., \& Taylor, A. (2008). Afghan hearts, Afghan Minds: Exploring Afghan perceptions of civil-military relations (Executive summary and recommendations). Brussels and London: European Network of NGOs in Afghanistan (ENNA) and the British and Irish Agencies Afghanistan Group (BAAG).

9. Baker, B. (2002). Living with non-state policing in South Africa: The issues and dilemmas.Journal of Modern African Studies, 40(1), 29-53.

10. Baker, B. (2008). Multi-choice policing in Africa. Uppsala: Nordiska Afrikainstitutet.

11. Barkindo, I. (2007, June). The role of the institution of Hisba in the Sharia implementing states in Northern Nigeria.MA thesis submitted to the Faculty of Law, Ahmadu Bello University, Zaria, Nigeria.

12. Bell, C. (2011). Civilianizing warfare: Ways of war and peace in modern counterinsurgency. Journal of International Relations and Development, 14, 309-332.

13. Berndtsson, J. (2009). The Privatisation of Security and State Control of Force: Changes, Challenges and the Case of Iraq. PhD thesis submitted at the School of Global Studies, University of Gothenburg, Gothenburg, Sweden.

14. Burchard, S. (2014). State-sponsored vigilantism in Nigeria and the fight against Boko Haram. Africa Watch, 4, 3-4.

15. Congressional Research Service. (2016). Nigeria's Boko Haram: Frequently asked questions. Washington: Washington Congressional Service.

16. Dietrich, K. (2015, April). When we can't see the enemy, the civilians become the enemy. Living through Nigeria's six-year insurgency. Washington: Center for Civilians in Conflict.

17. Dogarawa, A. B. (2011). Role of the Hisba (Ombudsmanship) institution in ensuring ethical business practices: Reflection for Sharia implementing states in Nigeria. Paper presented at the BEN-Africa conference at Zanzibar, Tanzania, on October 31 - November 2.

18. Enechojo, A. P. (2013). An assessment of the performance of internal security structures in community crime control in metropolitan Lagos. British Journal of Arts and Social Science, 14(1), 37-57.

19. ETTIS. (2012). A working definition of societal security (D.I.2). Deliverable submitted in November 2012 (M11) in fulfilment of the requirement of the FP7 project. Oslo: European Security Trends and Threats in Society (ETTIS), Norway.

20. Fourchard, L. (2011). A new name for an old practice: vigilante in South-western Nigeria. Africa: Cambridge University Press.

21. Gaffey, C. (2015, December 23). Anti-Boko Haram vigilantes pose challenges in WestAfrica. Newsweek World. Retrieved from http://europe.newsweek.com/boko-haramvigilantes-throw-new-challenges-nigeria-and-its-neighbours-408203?rm=eu.

22. Graff, L. L. (2002). Emerging trends and issues in volunteerism and volunteer program management. E-Volunteerism, III(1), 1-20.

23. Greenberg, M. A. (2005). Unveiling the concept of volunteer policing. Pittsburg: University of Pittsburgh Press. 
24. Haefele, B. (n.d.).Vigilantism in the Western Cape. Cape Town: Department of Community Safety, Provincial Government of West Cape.

25. Hassan, I. (n.d.). Counter Insurgency from below, the Need for Local Grassroots Defenders in Curbing the Insurgency in North-East Nigeria. Abuja: Center for Democracy and Development.

26. Horton, G. (2014). Conflict in Michoacán: Vigilante groups present challenges and opportunities for the Mexican Government. Michoacan: Wilson Center, Mexico Institute.

27. HRW/CLEEN Foundation. (2002). The Bakassi Boys: The legitimization of murder and torture. Report of Human Rights Watch and CLEEN Foundation, 14(5), 2-45.

28. Human Rights Council. (2015, September). Report of the United Nations High Commission for Human Rights violations and abuses committed by Boko Haram and their impact in human right in the affected countries. Geneva: Office of the United Nations High Commission for Human Rights.

29. International Crisis Group. (2010, December 20). Northern Nigeria: Background to conflict. A Report of the International Crisis Group, No. 168. Retrieved from www.cri sisgroup.org/africa/west-africa/nigeria/northern-nigeria-background-conflict.

30. International Crisis Group (2014, April 3). Curbing violence in Nigeria (II): Boko Haram insurgency. International Crisis Group's African Report, N0 216. Retrieved from www. crisisgroup.org/africa/west-africa/nigeria/curbing-violence-nigeria-ii-boko-haraminsurgency.

31. Jarman, N. (2007). Vigilantism, transition and legitimacy: Internal policing in Northern Ireland. In D.Pratten and A. Sen (Eds.), Global Vigilantes: Anthropological Perspectives on justice and violence (pp. 1-22). London: Hurst.

32. Kantor, A. \& Persson, M. (2010). Understanding vigilantism: informal security providers and security sector reform in Liberia. Sandöverken: Folke Bernadotte Academy

33. Kyed, H. M. (2009). Community policing in post-war Mozambique. Policing and Society, $19(4), 354-371$.

34. Matfess, H. (2016). Institutionalizing instability: The constitutional roots of insecurity in Nigeria's Fourth Republic. Stability: International Journal of Security and Development, 59(1), 1-19.

35. May, R. J. (1992). Vigilantes in the Philippines from fanatical cults to citizens' organizations. Philippines Studies Occasional Papers No 12. Honolulu: Center for Philippines Studies, School of Hawaiian, Asian and Pacific Studies, University of Hawaii at Monoa.

36. Mbogo, J., Ndung'u, J., Campbell, I., \& Rai, S. (2008). Implementing community based policing in Kenya. London: Saferworld

37. McCall, J. C. (2004). Juju and justice at the movies: Vigilantes in Nigerian popular videos. African studies Review, 47(3), 51-67.

38. MDGs-Nigeria. (2013). 2013 Report of the Millennium Development Goals, Nigeria. Abuja: MDGs-Nigeria.

39. Newby, B. (2012). Watchful guardian or dark knights: The vigilantes as a social order. Naples: International Foundations for Protection Officers (IFPO). 
40. Ngare, L. (2012). Politics of ethnic and religious alignments in Nigeria: A philosophy of mutual co-existence. Jos: Fab Annieh Nig.

41. Nielsen, R. W. R. (2013). Civic engagement- a cornerstone of contemporary America. An examination of civic engagement in America society. BA thesis submitted in the School of Business and Social Sciences, Aarhus University, Aarhus, Denmark.

42. NSRP. (2016, January). Conflict briefing notes, No. 32. Abuja: Nigeria Stability and Reconciliation Programme.

43. Odomovo, A. S. (2014). Insurgency, counterinsurgency and human rights violations in Nigeria. The Age of Human Rights Journal, 3, 46-62.

44. Okeke, V. O. S. (2013). Community policing, vigilante security apparatus and security challenges in Nigeria: A lesson from Britain and Igbo traditional society of Nigeria. British Journal of Arts and Social Science, 14(11), 306-323.

45. Okoli, A. C. \& Okpaleke, F. N. (2013). Re-examining federalism in Nigeria: Some reflections. NASHER Journal, 11(1), 58-65.

46. Okoli, A. C. (2014). Disaster management and national security in Nigeria: The nexus and the disconnect. International Journal of Liberal art and Social Science, 2(1), 21-59.

47. Okoli, A. C. \& Iortyer, P. (2014). Terrorism and humanitarian crisis in Nigeria: Insights from Boko Haram insurgency. Global Journal of Human Social Science, 4(1.1), 39-50.

48. Onwudiwe, I. D. (2009). Community policing: The case of informal policing in Nigeria. In D. Wiser and I. D. Onwudiwe (Eds.), Community policing: International patterns and comparative perspectives (pp. 81-101). Boca Raton: CRC Press.

49. Sederberg, P. (1978). The phenomenology of vigilantism in contemporary America: An interpretation. Terrorism: An International Journal, 1(3/4), 287-305.

50. Selbee, L. K. (2004). Volunteering in Canada: An application of social resources theory to the likelihood of being a volunteer, and to the determination of volunteer effort. PhD. thesis submitted to the Faculty of Graduate Studies and Research, Carleton University, Ottawa, Ontario

51. Sliwinski, K. (2013). Counterterrorism- a comprehensive approach; social mobilization and civilianization. Hong Kong: Hong Kong University, Department of Government and International Studies.

52. Stovenson, J. (2015, January). Statistical analysis of event data concerning Boko Haram in Nigeria (2009-2013). Maryland: National Consortium to terrorism, University of Maryland.

53. Today. (2016, March 30). 10,000 hunters converge in Northeast, want to confront Boko Haram in Sambisa. Today. Retrieved from www.today.ng/news/nigeria/99438/10000hunters-converge-in-north-east-want-to-confront-boko-haram-in-sambisa.

54. WANEP-Nigeria. (2015, July). National Early Warning System (NEWS). Weekly highlight, 12-18 July, 2015. Abuja: West Africa Network for Peace-building, Nigeria.

55. Watch List. (2014, September). Who will care for us? Grave violations against children in North East Nigeria. New York: Watch List Report on children and armed conflict.

56. Wu, H. (2011, August). Social impact of volunteerism. Atlanta: Points of Light Institute. 


\section{Appendix I: Diary of Interviews/Discussions}

\begin{tabular}{|c|c|c|c|}
\hline Name & Designation & $\begin{array}{c}\text { Interview/discussion } \\
\text { Destination }\end{array}$ & $\begin{array}{c}\text { Interview/discussions } \\
\text { date }\end{array}$ \\
\hline Anonymous & Military personnel & Abuja, Nigeria & May 31, 2016 \\
\hline Anonymous & Military personnel & Abuja, Nigeria & May 31, 2016 \\
\hline Anonymous & Ex-vigilante/resident & $\begin{array}{l}\text { Maiduguri, Borno State, } \\
\text { Nigeria }\end{array}$ & May 23, 2016 \\
\hline Johnson Tifiti & $\begin{array}{l}\text { Postgraduate } \\
\text { student/ lecturer }\end{array}$ & $\begin{array}{l}\text { Mubi, Adamawa State, } \\
\text { Nigeria }\end{array}$ & May 24, 2016 \\
\hline Shehu Gusau & Lecturer/researcher & $\begin{array}{l}\text { Gashua, YobeState, } \\
\text { Nigeria }\end{array}$ & May 25, 2016 \\
\hline Lenshie Edward & Lecturer/researcher & $\begin{array}{l}\text { Jalingo, Taraba State } \\
\text { Nigeria }\end{array}$ & My 29, 2016 \\
\hline Anonymous & Community resident & $\begin{array}{l}\text { Kashare, Gombe State, } \\
\text { Nigeria }\end{array}$ & May 31, 2016 \\
\hline Sundry others & Various & Various & May-June, 2016 \\
\hline
\end{tabular}

